\title{
Lithium's Emerging Role in the Treatment of Refractory Major Depressive Episodes: Augmentation of Antidepressants
}

\author{
Michael Bauer ${ }^{a, b} \quad$ Mazda Adli ${ }^{b, c}$ Tom Bschor ${ }^{a, b, d}$ Maximilian Pilhatsch ${ }^{a}$ \\ Andrea Pfenniga, $^{a} \quad$ Johanna Sasse ${ }^{a, b}$ Rita Schmid $^{e}$ Ute Lewitzka $^{a, b}$ \\ ${ }^{a}$ Department of Psychiatry and Psychotherapy, University Hospital Carl Gustav Carus, Technische \\ Universität Dresden, Dresden, ${ }^{\mathrm{b}}$ The International Group for the Study of Lithium-Treated Patients, IGSLI, \\ 'Department of Psychiatry and Psychotherapy, Charité - Universitätsmedizin Berlin, Charité Campus Mitte, and \\ ${ }^{\mathrm{d} D e p a r t m e n t}$ of Psychiatry, Schlosspark-Clinic, Berlin, and e Department of Psychiatry and Psychotherapy, \\ University Medical Center Regensburg, Regensburg, Germany
}

\section{Key Words}

Lithium • Augmentation treatment strategies •

Antidepressants · Treatment-resistant depression

\begin{abstract}
Background: The late onset of therapeutic response and a relatively large proportion of nonresponders to antidepressants remain major concerns in clinical practice. Therefore, there is a critical need for effective medication strategies that augment treatment with antidepressants. Methods: To review the available evidence on the use of lithium as an augmentation strategy to treat depressive episodes. $\boldsymbol{R} \boldsymbol{e}$ sults: More than 30 open-label studies and 10 placebo-controlled double-blind trials have demonstrated substantial efficacy of lithium augmentation in the acute treatment of depressive episodes. Most of these studies were performed in unipolar depression and included all major classes of antidepressants, however mostly tricyclics. A meta-analysis including 10 randomized placebo-controlled trials has provided evidence that lithium augmentation has a statistically significant effect on the response rate compared to placebo with an odds ratio of 3.11 , which corresponds to a number-
\end{abstract}

needed-to-treat of 5 . The meta-analysis revealed a mean response rate of $41.2 \%$ in the lithium group and $14.4 \%$ in the placebo group. One placebo-controlled trial in the continuation treatment phase showed that responders to acutephase lithium augmentation should be maintained on the lithium-antidepressant combination for at least 12 months to prevent early relapses. Preliminary studies to assess genetic influences on response probability to lithium augmentation have suggested a predictive role of the $-50 \mathrm{~T} / \mathrm{C}$ single nucleotide polymorphism of the GSK3 $\beta$ gene. Conclusion: Augmentation of antidepressants with lithium is currently the best-evidenced augmentation therapy in the treatment of depressed patients who do not respond to antidepressants.

Copyright $\odot 2010$ S. Karger AG, Basel

\section{History of Lithium in Depression}

Since the discovery of lithium in modern psychiatry in 1949, lithium has been mainly considered as a prophylactic treatment for bipolar disorders and an acute treatment of mania. Less attention has been given to lithium

\section{KARGER}

Fax +41613061234 E-Mail karger@karger.ch www.karger.com
(C) 2010 S. Karger AG, Basel

$0302-282 \mathrm{X} / 10 / 0621-0036 \$ 26.00 / 0$

Accessible online at:

www.karger.com/nps
Michael Bauer, MD, PhD

Department of Psychiatry and Psychotherapy, University Hospital Carl Gustav Carus Technische Universität Dresden, Fetscherstrasse 74, DE-01307 Dresden (Germany)

Tel. +49351 458 2772, Fax +49351 4584324

E-Mailmichael.bauer@uniklinikum-dresden.de 
and its potential value to treat and prevent acute depressive episodes in unipolar depression $[1,2]$. As early as in the 1960s and 70s, the antidepressant effect of lithium was investigated by numerous studies. Although there is quite some evidence from these studies for an antidepressive efficacy, lithium has never been used broadly as an antidepressant medication in unipolar and bipolar depressed patients in clinical practice. The maintenance properties of lithium were investigated since the late 1950s in both bipolar and unipolar affective illness. Many of these studies which focused on bipolar disease also had substantial data on the prophylactic effects of lithium in preventing the recurrence of unipolar depression. A recent comprehensive review of these studies shows that lithium prevents the recurrence of unipolar depression [1]. However, despite these findings the evidence failed to convince practitioners to use lithium to treat acute and prophylactic depressive disorders. This might be due to its relatively narrow therapeutic range of application and the necessity with lithium treatment to monitor lithium serum level regularly. The focus of this article is on another effective application of lithium in the treatment of depressive disorders that emerged since the 1980s: lithium augmentation of antidepressants.

\section{Augmentation Therapy in Depression}

Although there are many drugs available for the treatment of major depression, the overall treatment outcome of depressed patients is usually far from optimal. Regardless of the initial choice of antidepressant, about 30-50\% of patients with a major depressive episode will not respond sufficiently to adequately performed first-line treatment [3]. Numerous treatment strategies have been described for use in antidepressant nonresponder and treatment-resistant depression [4, 5]. Augmentation treatment strategies involve adding a second drug other than an antidepressant to the treatment regimen when no response or only partial response has been achieved, with the goal of enhancing treatment. Augmentation agents include lithium, thyroid hormones, atypical neuroleptics, anticonvulsants, stimulants and buspirone. One advantage of augmentation is that it eliminates the period of transition between 1 antidepressant to another and builds on the partial response. Consequently, when they work, augmentation strategies can have a rapid effect. Secondly, augmentation is of benefit for patients who have had some response and may be reluctant to risk losing that improvement [3].

Lithium Augmentation
Of these strategies, lithium augmentation therapy is among the best-studied ones [6]. Lithium salts have been used to augment the efficacy of antidepressant medications for more than 25 years. The first study to test this hypothesis in patients with major depression was performed by de Montigny et al. [7]. They reported a dramatic response within $48 \mathrm{~h}$ to the addition of lithium in 8 patients who had not responded to at least 3 weeks of treatment with tricyclic antidepressants. The efficacy of the combination and rapidity of response has led many clinical research groups to pursue study of this treatment intervention. Subsequent randomized controlled trials have confirmed de Montigny's initial findings from 1981 with more than 30 open-label and comparator studies including more than 500 depressed patients being published [8]. In these studies, the duration of antidepressant before treatment ranged between 3 and 7 weeks with a mean of 4.5 weeks; the subsequent lithium augmentation therapy lasted between 2 days and 14 weeks with a mean duration of about 30 days. The antidepressants used in the trials included agents from different groups; among them were selective serotonin reuptake inhibitors (SSRIs), tri- and tetracyclic antidepressants, and monoamine oxidase inhibitors. The dosages of the antidepressants used were not reported in all trials. The dosages of lithium carbonate ranged between 300 and 1,500 mg/ day. The response rates ranged widely between 100 and $23.5 \%$ with a median of $56 \% ; 10$ of 17 open-label studies found response rates to lithium augmentation of $50 \%$ or more.

A recent meta-analysis addressing the question pooled 10 randomized, double-blind, placebo-controlled trials and included 269 mostly unipolar depressed patients [9]. Lithium dosage, duration of treatment and other characteristics of the studies are detailed in table 1. Lithium had a significant positive effect versus placebo with an odds ratio of 3.11, which corresponds to a number-needed-totreat of 5. Table 1 shows the odds ratio for subjects responding to the treatment in each study by year of publication.

However, 5 of the studies pooled did not show a significant difference. Reasons for the negative findings may be low power [10-12], use of insufficient lithium doses [13], too short a duration of treatment $[10,12]$, and concerns about the efficacy of lithium augmentation with noradrenergic antidepressants $[14,15]$. Previous studies had demonstrated that only doses of lithium carbonate higher than $600 \mathrm{mg} /$ day and a duration of 7 days were useful in augmenting therapies [16].

Neuropsychobiology 2010;62:36-42 
Table 1. Results of randomized, placebo-controlled lithium augmentation studies in depression

\begin{tabular}{|c|c|c|c|c|c|}
\hline Study & Subjects & Antidepressant & $\begin{array}{l}\text { Lithium dosage (serum level) and } \\
\text { duration }\end{array}$ & $\begin{array}{l}\text { Fixed effects: } \\
\text { odds ratio }{ }^{\mathrm{a}}(95 \% \mathrm{CI})\end{array}$ & $\begin{array}{l}\text { Response criteria; } \\
\text { response rates }\end{array}$ \\
\hline $\begin{array}{l}\text { Heninger et al. } \\
{[47], 1983}\end{array}$ & $\begin{array}{l}14 \mathrm{UP}, 1 \mathrm{BP} \\
12 \mathrm{~F}, 3 \mathrm{M} \\
\text { mean age } 50 \text { years }\end{array}$ & $\begin{array}{l}\text { various TCAs } \\
\text { and tetracyclics }\end{array}$ & $\begin{array}{l}\text { lithium carbonate } 900-1,200 \mathrm{mg} / \text { day } \\
(0.5-1.1 \mathrm{mEq} / \mathrm{l}) \\
12 \text { days }\end{array}$ & $23.57(1.00-556.08)$ & $\begin{array}{l}\text { decrease of } 2 \text { or more } \\
\text { points on SCRS; } \\
\text { lithium: } 62.5 \% \\
\text { placebo: } 0 \%\end{array}$ \\
\hline $\begin{array}{l}\text { Kantor et al. } \\
{[10], 1986}\end{array}$ & $\begin{array}{l}7 \text { UP } \\
\text { sex nr } \\
\text { mean age nr }\end{array}$ & various TCAs & $\begin{array}{l}\text { lithium carbonate } 900 \mathrm{mg} / \text { day } \\
48 \mathrm{~h}\end{array}$ & $3.00(0.09-102.05)$ & $\begin{array}{l}\geq 40 \% \text { decrease in } \\
\text { HAM-D score; } \\
\text { lithium: } 25 \% \\
\text { placebo: } 0 \%\end{array}$ \\
\hline $\begin{array}{l}\text { Zusky et al. } \\
{[11], 1988}\end{array}$ & $\begin{array}{l}16 \mathrm{UP} \\
13 \mathrm{~F}, 3 \mathrm{M} \\
\text { mean age } 45 \text { years }\end{array}$ & $\begin{array}{l}\text { various TCAs } \\
\text { and MAOIs }\end{array}$ & $\begin{array}{l}\text { lithium carbonate } 300 \mathrm{mg} / \text { day first } \\
\text { week, } 900 \mathrm{mg} / \text { day second week } \\
14 \text { days }\end{array}$ & $1.80(0.21-15.41)$ & $\begin{array}{l}\text { final HAM-D score } \leq 7 \\
\text { lithium: } 38 \% \\
\text { placebo: } 25 \%\end{array}$ \\
\hline $\begin{array}{l}\text { Schöpf et al. } \\
{[30], 1989}\end{array}$ & $\begin{array}{l}18 \mathrm{UP}, 9 \mathrm{BP} \\
19 \mathrm{~F}, 8 \mathrm{M} \\
\text { mean age } 54 \text { years }\end{array}$ & $\begin{array}{l}\text { various } \\
\text { antidepressants }\end{array}$ & $\begin{array}{l}\text { lithium carbonate } 600-800 \mathrm{mg} / \text { day } \\
(0.6-0.8 \mathrm{mEq} / \mathrm{l}) \\
7 \text { days }\end{array}$ & $27.00(1.35-541.57)$ & $\begin{array}{l}\geq 50 \% \text { decrease in HAM-D; } \\
\text { lithium: } 50 \% \\
\text { placebo: } 0 \%\end{array}$ \\
\hline $\begin{array}{l}\text { Browne et al. } \\
{[12], 1990}\end{array}$ & $\begin{array}{l}14 \mathrm{UP}, 3 \mathrm{BP} \\
10 \mathrm{~F}, 7 \mathrm{M} \\
\text { mean age } 42 \text { years }\end{array}$ & $\begin{array}{l}\text { various TCAs } \\
\text { and tetracyclics }\end{array}$ & $\begin{array}{l}\text { lithium carbonate } 900 \mathrm{mg} / \text { day } \\
48 \mathrm{~h}\end{array}$ & $3.00(0.35-25.87)$ & $\begin{array}{l}\geq 50 \% \text { decrease in HAM-D; } \\
\text { lithium: } 43 \% \\
\text { placebo: } 20 \%\end{array}$ \\
\hline $\begin{array}{l}\text { Stein and } \\
\text { Bernadt } \\
{[13], 1993}\end{array}$ & $\begin{array}{l}34 \mathrm{UP} \\
27 \mathrm{~F}, 7 \mathrm{M} \\
\text { mean age } 47 \text { years }\end{array}$ & various TCAs & $\begin{array}{l}\text { lithium carbonate } 250 \mathrm{mg} / \text { day or } \\
750 \mathrm{mg} / \text { day } \\
21 \text { days }\end{array}$ & $0.50(0.08-3.19)$ & $\begin{array}{l}\geq 50 \% \text { decrease in HAM-D; } \\
\text { lithium }(250 \mathrm{mg}): 18 \% \\
\text { lithium }(750 \mathrm{mg}): 44 \% \\
\text { placebo: } 22 \%\end{array}$ \\
\hline $\begin{array}{l}\text { Joffe et al. } \\
{[21], 1993}\end{array}$ & $\begin{array}{l}33 \mathrm{UP} \\
18 \mathrm{~F}, 15 \mathrm{M} \\
\text { mean age } 37 \text { years }\end{array}$ & various TCAs & $\begin{array}{l}\text { lithium carbonate } 900 \mathrm{mg} / \text { day } \\
(>0.55 \mathrm{mEq} / \mathrm{l}) \\
14 \text { days }\end{array}$ & $4.88(1.01-23.57)$ & $\begin{array}{l}\geq 50 \% \text { decrease in HAM-D; } \\
\text { lithium: } 52 \% \\
\text { placebo: } 18.7 \%\end{array}$ \\
\hline $\begin{array}{l}\text { Katona et al. } \\
{[48], 1995}\end{array}$ & $\begin{array}{l}\text { 61, polarity } \mathrm{nr} \\
35 \mathrm{~F}, 26 \mathrm{M} \\
\text { mean age } 40 \text { years }\end{array}$ & SSRI and TCA & $\begin{array}{l}\text { lithium } 800 \mathrm{mg} / \text { day }(0.6-1 \mathrm{mmol} / \mathrm{l}) \\
42 \text { days }\end{array}$ & $3.21(1.09-9.48)$ & $\begin{array}{l}\geq 50 \% \text { decrease in HAM-D; } \\
\text { lithium: } 53 \% \\
\text { placebo: } 25 \%\end{array}$ \\
\hline $\begin{array}{l}\text { Baumann et al. } \\
\text { [49], } 1996\end{array}$ & $\begin{array}{l}23 \mathrm{UP}, 1 \mathrm{BP} \\
17 \mathrm{~F}, 7 \mathrm{M} \\
\text { mean age } 41 \text { years }\end{array}$ & $\begin{array}{l}\text { SSRI } \\
\text { (citalopram) }\end{array}$ & $\begin{array}{l}\text { lithium carbonate } 800 \mathrm{mg} / \text { day } \\
(0.5-0.8 \mathrm{mmol} / \mathrm{l}) \\
7 \text { days }\end{array}$ & $9.00(1.27-63.89)$ & $\begin{array}{l}\geq 50 \% \text { decrease in HAM-D; } \\
\text { lithium: } 58 \% \\
\text { placebo: } 14 \%\end{array}$ \\
\hline $\begin{array}{l}\text { Nierenberg et al. } \\
{[14], 2003}\end{array}$ & $\begin{array}{l}35 \mathrm{UP} \\
16 \mathrm{~F}, 19 \mathrm{M} \\
\text { mean age } 38 \text { years }\end{array}$ & $\begin{array}{l}\text { TCA } \\
\text { (nortriptyline) }\end{array}$ & lithium carbonate $900 \mathrm{mg} /$ day & $0.58(0.08-4.01)$ & $\begin{array}{l}\geq 50 \% \text { decrease in HAM-D; } \\
\text { lithium: } 12.5 \% \\
\text { placebo: } 20 \%\end{array}$ \\
\hline
\end{tabular}

$\mathrm{UP}=$ Unipolar; $\mathrm{BP}=$ bipolar; $\mathrm{F}$ = female; $\mathrm{M}=$ male; $\mathrm{nr}=$ not reported MAOI = monoamine oxidase inhibitor; $\mathrm{TCA}=$ tricyclic antidepressant; $\mathrm{HAM}$ $\mathrm{D}=$ Hamilton Depression Rating Scale; SCRS = Short Clinical Rating Scale; CI = confidence interval .

a All studies: odds ratio 3.11 (1.80-5.37); data from meta-analysis.

Since the first meta-analysis [16], only 1 placebo-controlled study has been published [14]. As noted on the original meta-analysis published in 1999 [16], a new negative study would have to include more than 2,500 patients per group to change the results of this pooling. However, it remains to be examined whether the response to lithium augmentation represents true augmentation resulting from synergistic effects or whether the response is simply owing to the antidepressant effect of lithium itself. Experimental studies supporting the former possibility will be reviewed below. From the clinical point of view, arguments for a true augmentation effect derive from a controlled clinical trial showing that the antidepressant effects of lithium addition were significantly higher in amitriptyline-pretreated depression patients, compared with placebo-pretreated patients, who showed no improvement after a 3-week treatment [17]. In summary, a randomized, double-blind study is warranted which investigates the effects of lithium alone and compares them with the effects of lithium in combination with an antidepressant. 


\section{Comparator Studies of Lithium Augmentation}

Rarely have two augmentation strategies been compared with each other under similar conditions, thus the relative magnitude of their effects is largely unknown. Among the comparators were electroconvulsive therapy [18], monoamine oxidase inhibitors [19, 20], thyroid hormone [21], carbamazepine [22, 23], and high-dose SSRIs or tricyclic augmentation in SSRI users [24]. In these studies, there has been no dramatic difference between lithium augmentation and any other strategy, although the varied quality of some studies - for example problems with trial duration, use of subtherapeutic doses of lithium and low power - should preclude drawing definite conclusions.

\section{Continuation Phase and Discontinuation Studies}

One randomized controlled trial has examined the efficacy of lithium augmentation in the continuation treatment phase of unipolar major depressive disorder [25]. Twenty-nine patients with a refractory major depressive episode, single or recurrent, who had responded to acute lithium augmentation therapy during an open-label 6 week study were randomized after a 2- to 4 -week stabilization period to a double-blind continuation treatment for another 4 months with either lithium $(n=14)$ or placebo $(n=15)$. The antidepressant was continued at the same dosage throughout the study. Seven of the 15 patients on placebo suffered from a relapse (5 depressive and 2 with a first manic episode) in the double-blind study phase, while no patients from the lithium group relapsed. Even more patients relapsed during the subsequent open-label 6-month phase after lithium was withdrawn in the group previously receiving lithium [26]. It was concluded that patients who respond to lithium augmentation should be maintained on lithium augmentation for a minimum of 12 months or even longer [26].

The effects of gradual discontinuation of lithium augmentation therapy were assessed in a randomized, placebo-controlled discontinuation study in 12 elderly patients who had responded to lithium augmentation during their most recent refractory unipolar depressive episode [27]. Patients were randomized to receive continued lithium augmentation or matching placebo; 2 of 6 patients in the lithium maintenance group had a recurrence of depression at 61 and 96 weeks, respectively, immediately after a stressful life event. Similarly, 2 of 6 patients had a recurrence in the placebo group at 7 and 92 weeks, respectively, without any apparent changes in life stresses. In a second, naturalistic discontinuation study in an elderly group of patients with major depressive disorder, about half of the patients relapsed following discontinuation of lithium augmentation [28]. In a recent review article [29], it was concluded that there is a significant risk of relapse in elderly patients whose lithium augmentation therapy for unipolar depression is discontinued.

\section{Predictors of Response and Practical Use of Lithium Augmentation}

A series of studies have investigated clinical and biological factors in lithium augmentation trials to allow outcome prediction [17,30-33]. Age and gender have consistently been found not to be associated with response. Some studies have observed that bipolar patients respond better than unipolar patients [34], but this has not been confirmed by others, likely because most patients enrolled in the augmentation studies suffered from unipolar depression [35]. An analysis of 71 depressed patients refractory to treatment with a tricyclic antidepressant demonstrated that patients with a more severe depressive syndrome were more likely to respond to lithium augmentation [33].

During the past decade, we have administered lithium augmentation in a fast titrating regimen in adults without major adverse events in depressed in- and outpatients. In adults (age up to 55 years; in elderly patients slower), lithium carbonate is started on a daily dose of $450 \mathrm{mg}$ (equivalent to approximately $12 \mathrm{mmol} /$ day), and the dose is increased to $900 \mathrm{mg}$ on the second day. This scheme leads to lithium serum levels of $0.5-0.7 \mathrm{mmol} / \mathrm{l}$ in most patients. The first dose adjustment can be performed after achieving a steady state, typically 5 days after the last change in dosing. Treatment of about 4 weeks allows assessment of the patient's response.

\section{Mechanisms of Lithium Augmentation}

The underlying mechanisms of action involved in the potentiatory effect of lithium is still unclear and several hypotheses have been suggested such as activity and modulation on serotonin (5-HT) neurotransmission and endocrine systems [36-38]. Initially, de Montigny and colleagues $[17,39]$ postulated that a pharmacodynamic action mediated via the serotonergic systems may ac- 
count for the synergistic effect of lithium when added to a tricyclic antidepressant. From animal studies there is robust evidence that lithium augmentation increases 5HT neurotransmission, possibly through a synergistic action of lithium and the antidepressant on brain 5-HT pathways. Using microdialysis techniques in animals, addition of lithium to chronic citalopram therapy further elevated basal levels of 5-HT in the rat ventral hippocampus [40]. Further evidence for a 'true' augmentation effect derived from animal studies showed that, in contrast to lithium alone, the addition of lithium to antidepressant treatment with the SSRI, citalopram potentiated presynaptic serotonergic function in rats [41]. Specifically, some authors suggested that the effect of lithium on 5-HT neurotransmission could be linked to a partial agonist activity on 5-HT1B autoreceptors or to a modulatory activity on these receptors [38]. In a recent series of experiments, the effects of lithium were investigated in a battery of standard behavioral tests (e.g. Porsolt's forced swim test, open-field test) that are considered animal models of depression. In these studies, behavior was robustly affected dose dependently by chronic lithium treatment $[42,43]$ suggesting lithium's genuine antidepressant properties. Remarkably, these lithium-sensitive behaviors were also observed in mice lacking one copy of the gene encoding GSK3 $\beta$, a well-established direct target of lithium [42].

Pharmacogenetic approaches to assess genetic influences on response probability to lithium augmentation have also revealed some promising results. In a pilot study, the 5-HT transporter gene-linked polymorphic region (5-HTTLPR) allele variant's effect on lithium augmentation was analyzed in 50 antidepressant-nonresponsive patients [44]. Patients homozygous for the s allele of the 5-HTTLPR had a more favorable response compared

previously been shown to be associated with response to lithium prophylaxis in bipolar disorder [46]. Similarly, carriers of the $\mathrm{C}$ allele of the $-50 \mathrm{~T} / \mathrm{C}$ SNP showed a significantly better response to lithium augmentation (hazard ratio $=2.70, p=0.007$ ) with a mean remission rate of $56.2 \%$ after 4 weeks compared to $31 \%$ in patients with the TT genotype [45]. These results suggest a predictive role of the $-50 \mathrm{~T} / \mathrm{C}$ SNP of the GSK3 $\beta$ gene for response to lithium augmentation treatment in depressed patients who do not respond sufficiently to monotherapy with an antidepressant. However, these promising data require confirmation in larger samples to be applicable in clinical routine care. Also, the functional relevance of the GSK3 $\beta$ $-50 \mathrm{~T} / \mathrm{C}$ SNP needs to be further investigated.

\section{Conclusion}

Augmentation of antidepressants with lithium is the best-evidenced augmentation therapy in the treatment of depressed patients who do not respond to standard antidepressants. The evidence reviewed here supports the recommendation of lithium augmentation as a first-line therapy for nonresponding and refractory depressed patients $[3,4,6]$. In depressed patients who respond to lithium augmentation, effective lithium doses should be continued in combination with the antidepressant for at least 12 months after remission, in those patients with recurrent depression even longer [25]. Unfortunately, this effective and generally well-tolerated strategy is widely underutilized in clinical practice. with those heterozygous (hazard ratio $=6.9 ; \mathrm{p}=0.005$ ) or homozygous for the l allele (hazard ratio $=4.5 ; \mathrm{p}=0.003$ ). These findings support a differential effect of the 5-HTTLPR gene on treatment augmentation and the s/s genotype might predict an individual's risk of antidepressant nonresponsiveness and sensitivity to augmentative drugs such as lithium.

Another pharmacogenetic study investigated the association of the GSK3 $\beta-50 \mathrm{~T} / \mathrm{C}$ single nucleotide polymorphism (SNP) and response to lithium augmentation in 81 unipolar depressed patients [45]. Inhibition of GSK3 $\beta$ - an intracellular kinase, highly expressed in the brain - has been associated with neurotrophic and neuroprotective effects. Most interestingly, lithium is a direct and significant inhibitor of GSK3 3 . A -50T/C SNP localized within the promoter region of the GSK3 $\beta$ gene has

\section{References}

1 Davis JM: Lithium maintenance of unipolar depression; in Bauer M, Grof P, Müller-Oerlinghausen B (eds): Lithium in Neuropsychiatry - The Comprehensive Guide. Abingdon, Informa Healthcare UK Ltd, 2006, pp 99-108.

2 Bauer M, Crossley NA, Gerber S, Bschor T: The acute antidepressive effects of lithium: from monotherapy to augmentation therapy in major depression; in Bauer M, Grof P, Müller-Oerlinghausen B (eds): Lithium in Neuropsychiatry - The Comprehensive Guide. Abingdon, Informa Healthcare UK Ltd, 2006, pp 109-127.

-3 Bauer M, Bschor T, Pfennig A, Whybrow PC, Angst J, Versiani M, Möller HJ: World Federation of Societies of Biological Psychiatry (WFSBP) guidelines for biological treatment of unipolar depressive disorders in primary care. World J Biol Psychiatry 2007;8:67-104.

Bauer/Adli/Bschor/Pilhatsch/Pfennig/ Sasse/Schmid/Lewitzka 
4 Bauer M, Whybrow PC, Angst J, Versiani M, Möller HJ: World Federation of Societies of Biological Psychiatry (WFSBP) guidelines for biological treatment of unipolar depressive disorders. 1. Acute and continuation treatment of major depressive disorder. World J Biol Psychiatry 2002;3:5-43.

5 Thase ME: Augmentation strategies for depression: history and concepts. CNS Spectr 2007;12(suppl 22):3-5

$\checkmark 6$ Carvalho AF, Machado JR, Cavalcante JL: Augmentation strategies for treatment-resistant depression. Curr Opin Psychiatry 2008; 22:7-12.

7 De Montigny C, Grunberg F, Mayer A, Deschenes JP: Lithium induces rapid relief of depression in tricyclic antidepressant drug non-responders. Br J Psychiatry 1981;138: 252-256.

$\checkmark 8$ Bauer M, Adli M, Baethge C, Berghöfer A, Sasse J, Heinz A, Bschor T: Lithium augmentation therapy in refractory depression: clinical evidence and neurobiological mechanisms. Can J Psychiatry 2003;48:440-446.

$\checkmark 9$ Crossley NA, Bauer M: Acceleration and augmentation of antidepressants with lithium for depressive disorders: two meta-analyses of randomized, placebo-controlled trials. J Clin Psychiatry 2007;68:935-940.

-10 Kantor D, McNevin S, Leichner P, Harper D, Krenn M: The benefit of lithium carbonate adjunct in refractory depression - fact or fiction? Can J Psychiatry 1986;31:416-418.

-11 Zusky PM, Biederman J, Rosenbaum JF, Manschreck TC, Gross CC, Weilberg JB, Gastfriend DR: Adjunct low-dose lithium carbonate in treatment-resistant depression: a placebo-controlled study. J Clin Psychopharmacol 1988;8:120-124.

-12 Browne M, Lapierre YD, Hrdina PD, Horn E: Lithium as an adjunct in the treatment of major depression. Int Clin Psychopharmacol 1990;5:103-110.

13 Stein G, Bernadt M: Lithium augmentation therapy in tricyclic-resistant depression. A controlled trial using lithium in low and normal doses. Br J Psychiatry 1993;162:634640.

-14 Nierenberg AA, Papakostas GI, Petersen T, Montoya HD, Worthington JJ, Tedlow J, Alpert JE, Fava M: Lithium augmentation of nortriptyline for subjects resistant to multiple antidepressants. J Clin Psychopharmacol 2003;23:92-95.

15 Bschor T, Bauer M: Is successful lithium augmentation limited to serotonergic antidepressants? J Clin Psychopharmacol 2004;24: 240-241.

$>16$ Bauer M, Döpfmer S: Lithium augmentation in treatment-resistant depression: metaanalysis of placebo-controlled studies. J Clin Psychopharmacol 1999;19:427-434.
7 de Montigny C, Cournoyer G, Morissette R, Langlois R, Caille G: Lithium carbonate neurobiologic actions of tricyclic antidepressant drugs and lithium ion on the serotonin system. Arch Gen Psychiatry 1983;40:13271334.

18 Dinan TG, Barry S: A comparison of electroconvulsive therapy with a combined lithium and tricyclic combination among depressed tricyclic nonresponders. Acta Psychiatr Scand 1989;80:97-100.

19 Hoencamp E, Haffmans PM, Dijken WA, Hoogduin CA, Nolen WA, van Dyck R: Brofaromine versus lithium addition to maprotiline. A double-blind study in maprotiline refractory depressed outpatients. J Affect Disord 1994;30:219-227.

20 Kok RM, Vink D, Heeren TJ, Nolen WA: Lithium augmentation compared with phenelzine in treatment-resistant depression in the elderly: an open, randomized, controlled trial. J Clin Psychiatry 2007;68:1177-1185.

21 Joffe RT, Singer W, Levitt AJ, MacDonald C: A placebo-controlled comparison of lithium and triiodothyronine augmentation of tricyclic antidepressants in unipolar refractory depression. Arch Gen Psychiatry 1993a;50: 387-393.

22 Rybakowski JK, Suwalska A, ChlopockaWozniak M: Potentiation of antidepressants with lithium or carbamazepine in treatment-resistant depression. Neuropsychobiology 1999;40:134-139.

23 Schüle C, Baghai TC, Eser D, Nothdurfter C, Rupprecht R: Lithium but not carbamazepine augments antidepressant efficacy of mirtazapine in unipolar depression: an open-label study. World J Biol Psychiatry 2008;25:1-10.

24 Fava M, Alpert J, Nierenberg A, Lagomasino I, Sonawalla S, Tedlow J, Worthington J, Baer L, Rosenbaum JF: Double-blind study of high-dose fluoxetine versus lithium or desipramine augmentation of fluoxetine in partial responders and nonresponders to fluoxetine. J Clin Psychopharmacol 2002;22: 379-387.

25 Bauer M, Bschor T, Kunz D, Berghöfer A Ströhle A, Müller-Oerlinghausen B: Doubleblind, placebo-controlled trial of the use of lithium to augment antidepressant medication in continuation treatment of unipolar major depression. Am J Psychiatry 2000;157: 1429-1435.

26 Bschor T, Berghöfer A, Ströhle A, Kunz D, Adli M, Müller-Oerlinghausen B, Bauer M: How long should the lithium augmentation strategy be maintained? A 1-year follow-up of a placebo-controlled study in unipolar refractory major depression. J Clin Psychopharmacol 2002;22:427-430.

$\checkmark 27$ Hardy BG, Shulman KI, Zucchero C: Gradual discontinuation of lithium augmentation in elderly patients with unipolar depression. J Clin Psychopharmacol 1997;17:22-26.
28 Fahy S, Lawlor BA: Discontinuation of lithium augmentation in an elderly cohort. Int J Geriatr Psychiatry 2001;16:1004-1009.

29 Ross J: Discontinuation of lithium augmentation in geriatric patients with unipolar depression: a systematic review. Can J Psychiatry 2008;53:117-120.

30 Schöpf J, Baumann P, Lemarchand T, Rey M: Treatment of endogenous depressions resistant to tricyclic antidepressants or related drugs by lithium addition. Results of a placebo-controlled double-blind study. Pharmacopsychiatry 1989;22:183-187.

-31 Joffe RT, Levitt AJ, Bagby RM, MacDonald C, Singer W: Predictors of response to lithium and triiodothyronine augmentation of antidepressants in tricyclic non-responders. Br J Psychiatry 1993b;163:574-578.

>32 Alvarez E, Perez-Sola V, Perez-Blanco J, Queralto JM, Torrubia R, Noguera R: Predicting outcome of lithium added to antidepressants in resistant depression. J Affect Disord 1997;42:179-186.

-33 Bschor T, Canata B, Müller-Oerlinghausen B, Bauer M: Predictors of response to lithium augmentation in tricyclic antidepressant-resistant depression. J Affect Disord 2001;64: 261-265.

34 Rybakowski J, Matkowski K: Adding lithium to antidepressant therapy: factors related to therapeutic potentiation. Eur Neuropsychopharmacol 1992;2:161-165.

>35 Price LH, Charney DS, Heninger GR: Variability of response to lithium augmentation in refractory depression. Am J Psychiatry 1986;143:1387-1392.

36 Chenu F, Bourin M: Potentiation of antidepressant-like activity with lithium: mechanism involved. Curr Drug Targets 2006;7: 159-163.

37 Bschor T, Adli M, Baethge C, Eichmann U, Ising M, Uhr M, Modell S, Künzel H, MüllerOerlinghausen B, Bauer M: Lithium augmentation increases the ACTH and cortisol response in the combined DEX/CRH test in unipolar major depression. Neuropsychopharmacology 2002;27:470-478.

38 Bschor T, Baethge C, Adli M, Eichmann U, Ising M, Uhr M, Modell S, Künzel H, MüllerOerlinghausen B, Bauer M: Association between response to lithium augmentation and the combined DEX/CRH test in major depressive disorder. J Psychiatr Res 2003;37: 135-143.

39 de Montigny C, Aghajanian GK: Tricyclic antidepressants: long-term treatment increases responsivity of rat forebrain neurons to serotonin. Science 1978;202:1303-1306.

40 Wegener G, Bandpey Z, Heiberg IL, Mork A, Rosenberg R: Increased extracellular serotonin level in rat hippocampus induced by chronic citalopram is augmented by subchronic lithium: neurochemical and behavioural studies in the rat. Psychopharmacology (Berl) 2003;166:188-194. 
-41 Okamoto Y, Motohasi N, Hayakawa H, Muraoka $M$, Yamawaki S: Addition of lithium to chronic antidepressant treatment potentiates presynaptic serotonergic function without changes in serotonergic receptors in the rat cerebral cortex. Neuropsychobiology 1996;33:17-20.

-42 O’Brien WT, Harper AD, Jové F, Woodgett JR, Maretto S, Piccolo S, Klein PS: Glycogen synthase kinase- $3 \beta$ haploinsufficiency mimics the behavioral and molecular effects of lithium. J Neurosci 2004;24:6791-6798.

43 Bersudsky Y, Shaldubina A, Belmaker RH: Lithium's effect in forced-swim test is blood level dependent but not dependent on weight loss. Behav Pharmacol 2007;18:77-80.
44 Stamm TJ, Adli M, Kirchheiner J, Smolka MN, Kaiser R, Tremblay PB, Bauer M: Serotonin transporter gene and response to lithium augmentation in depression. Psychiatr Genet 2008;18:92-97.

45 Adli M, Hollinde DL, Stamm T, Wiethoff K, Tsahuridu M, Kirchheiner J, Heinz A, Bauer M: Response to lithium augmentation in depression is associated with the glycogen synthase kinase 3-beta -50T/C single nucleotide polymorphism. Biol Psychiatry 2007;62: 1295-1302.

46 Benedetti F, Serretti A, Pontiggia A, Bernasconi A, Lorenzi C, Colombo C, Smeraldi E: Long-term response to lithium salts in bipolar illness is influenced by the glycogen synthase kinase 3-beta -50 T/C SNP. Neurosci Lett 2005;376:51-55.
47 Heninger GR, Charney DS, Sternberg DE: Lithium carbonate augmentation of antidepressant treatment. An effective prescription for treatment-refractory depression. Arch Gen Psychiatry 1983;40:1335-1342.

48 Katona CL, Abou-Saleh MT, Harrison DA, Nairac BA, Edwards DR, Lock T, Burns RA, Robertson MM: Placebo-controlled trial of lithium augmentation of fluoxetine and lofepramine.Br J Psychiatry 1995;166:80-86.

49 Baumann P, Nil R, Souche A, Montaldi S, Baettig D, Lambert S, Uehlinger C, Kasas A, Amey M, Jonzier-Perey M: A double-blind, placebo-controlled study of citalopram with and without lithium in the treatment of therapy-resistant depressive patients: a clinical, pharmacokinetic, and pharmacogenetic investigation. J Clin Psychopharmacol 1996; 16:307-314. 